\title{
ON SO-CALLED VASCULAR SPIDER IN LEPROSY PATIENTS
}

\author{
Sadatoshi UTSUNOMIYA, Korehiro IGUCAI, \\ Hiroshi IGAWA and Tatsuya HIDA. \\ (National Leprosarium, Oshima Seishoen)
}

Many cases of vascular spider have been observed in the leprosy patients in Oshima Seishoen. Up to now, no report was published on the relation of leprosy and this disease. This paper presents the results of the statistical observations and many kind of clinical exminations and refers to the etiology of this phenomenon.

1) Vascular spider was observed in $82,20.7 \%$, of 396 cases examined. The frequency is by far larger in leprosy than in other skin disease, and is conspicuously larger in the male than in the female (Fig. 1).

2) The manifestation of vascular spider is disposed to appear more frequently in tuberous leprosy (Tab. 4), in the ages ranging from 31 to 51 years old (Tab. 2), and in those who have the progress of disease from 11 to 20 years (Tab. 3).

3) Vascular spider predilects the upper half of the body, but it seems to have no correlation with the sensory disturbances (Tab. 5).

4) In all 38 cases of leprosy patients manifesting vascular spider, the disturbance of liver function was recognized, and the disturbance of interstitium is more intense than that of the parenchym (Tab. 4).

5) The double glucose tolerance test produced an anormal result in all 7 examined cases combined with vascular spider (Tab. 11).

6) The unbalance of autonomic nerve function is presented in nearly all of 10 cases (Tab. 12).

7) Thorn's epinephrin-test showed an anormal value in every case (Fig. 2).

8) The results of skin function tests were anormal (Tab. 6, 7, 8), and the difference caused by the existence of vascular spider was not clearly demonstrated.

9) Gynecomastia was found out in 6, 2.6\%, of 228 male leprosy patients and in 2, $2.9 \%$, of 69 patients combined with vascular spider.

10) The frequency of vascular spider in leprosy patients can be attributed to the superfluous circulating estrogen, which is caused by a decline of estrogen inactivating power due to the disturbances of liver function and the destruction of the inner genital and other endocrine organs.

\section{攋患者に見られたろ所謂 Vascular Spider について}

\author{
徳島大学医学部皮周科教室（指導 荒川忠良教授） \\ 国立療盖所 大島青松 園 (指導 野島泰治園長) \\ 宇都宮貞俊井口已広伊川裕飛田達哉 \\ (昭和29年11月25日受稿)
}

\section{緒古 \\ 肝硬変症に㕠々合併するといわれる 所謂 Vascular Spider（以下 VS と略記）は主として上半身皮蔵に発生}

する蜘蛛網状の毛細血管抎張であつて，E. Wilson（186

9) がはじめて Alcoholic hepatic cirrhosis の患者に認

め, Corbett (1914) は妊婦の本症に注意した。Eppinger

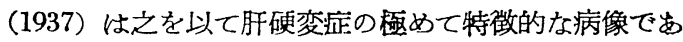


ると記載し, Cicovacki'(1940), Patek (1940), Bean （1943）等は夫々独自の立場からその発生病理, 組織所 見その他の方面から之を榆討した。本邦に於ては操教授 (1933)，故角尾教授（1941）により簡単に紹介されて いたが近年漸く注目せられるに至り，中尾・豊倉氏（19 50）等が詳細に綜説し，西原氏（1953）等は庭例を報告 した。谷村教授及び吉野氏（1953）はその臨牀的並びに 実験的研究からその本熊, 特に発生機序について検討 し, 肝臓の Estrogen 不活性化能力の減退による過剩の 血中 Estrogen が小動脈に作用して起るといら, Bean, Lloyd 等の説を支持し，平田氏（1953）は主として肝機 能障碍そ妊婦にみられる Hepatic palm を肺結核患者に 認め, 肝結核の際の肝障碍により循環 Estrogen の不活 性によるものであろろと推察された。

私達は国立療養所大島青松園に入園中の瀨患者の多数 にV S を認めたが，彷来瀬と本废との関連についての報 告を未だ見ないので各種の臨牀㭘査を行い，文献的に考 察してその成因心ついていささか触れて見たい。

\section{統計的锶察}

検診対象は昭和 28 年10月初旬より同月末に至る䦔に於 ける国立療羕所大島青松園入園者全員延651名（男432， 女 219 ) 中，事情（園内作業従事, 検診拒否々の他）に より検診出来なかつた者 225 名を除く男子 228 名, 女子 168名，計396名につきV S の有無を検索した。

1）出現率：被檢者総数 396 名心対しV Sを認めたも のは 82 名 $(20.7 \%$ \%) であり，特に男子に多発している (Tab. 1). その率は伊川が徳大医学部皮唐科教室に於 て昭和 $27 ， 28$ 両年度の皮愿科外来患者比 6 名 $(0.15 \%)$ 見たと報告した成績に比べると甚だ高率といわなければ ならない。

Tab. 1 VSの性別出現率

\begin{tabular}{|c|c|c|c|c|}
\hline & \multicolumn{2}{|c|}{ 瀨 患 者（青松園） } & \multicolumn{2}{|c|}{$\begin{array}{c}\text { 皮覤疾患 } \\
\text { (德大) }\end{array}$} \\
\hline & 被検者数 & $\begin{array}{c}\text { V S 合併者数 } \\
(\%)\end{array}$ & 患者数 & V S \\
\hline 男 子 & 228 & $69(30.2)$ & & 1 \\
\hline 女子 & 168 & $13(7.9)$ & & 5 \\
\hline 計 & 396 & $82(20.7)$ & 3811 & 6 \\
\hline
\end{tabular}

年令別に観察すると最低は19才，最高は77才であつた が過半数は31〜50才の間にあり，61才以上は少ない。

(Tab. 2).
Tab. 2 VSの年令別出現率

\begin{tabular}{|c|c|c|c|}
\hline 年令 & 被検者 & VS & $\begin{array}{c}\text { 出現 } \\
(\text { 率 }\end{array}$ \\
\hline$\sim 20$ & 12 & 1 & 8.3 \\
\hline$\sim 30$ & 104 & 11 & 10.6 \\
\hline$\sim 40$ & 102 & 31 & 30.3 \\
\hline$\sim 50$ & 82 & 27 & 32.9 \\
\hline$\sim 60$ & 57 & 10 & 17.5 \\
\hline $61 \sim$ & 39 & 2 & 5.1 \\
\hline 計 & 396 & 82 & 20.7 \\
\hline-2
\end{tabular}

瀨の経過年数との関係は11〜20年を経過したものが $/ 3$ を占め，率として75\%に当る。（Tab. 3 ）

Tab. 3 瀨の経過年数とVS

\begin{tabular}{|c|c|c|c|}
\hline 年数 & 被検者 & VS & $\begin{array}{c}\text { 出現 } \\
(\%)\end{array}$ \\
\hline$\sim 5$ & 57 & 5 & 8.7 \\
\hline$\sim 10$ & 94 & 8 & 8.5 \\
\hline$\sim 15$ & 87 & 30 & 34.4 \\
\hline$\sim 20$ & 84 & 25 & 29.7 \\
\hline$\sim 25$ & 44 & 7 & 15.9 \\
\hline$\sim 30$ & 30 & 7 & 23.3 \\
\hline 詇 & 396 & 82 & 20.7 \\
\hline
\end{tabular}

病型別に見ると結節癩，神経瀬，玟紋瀨の順序となり 結節瀨に最も高率であつた。（Tab.4）

Tab. 4VSの病型別出現率

\begin{tabular}{|c|c|c|c|}
\hline 病 型 & 被検者 & VS & $\begin{array}{l}\text { 出 現 率 } \\
(\%)\end{array}$ \\
\hline L & 272 & 65 & 23.9 \\
\hline M & 30 & 6 & 20.0 \\
\hline $\mathrm{N}$ & 94 & 11 & 11.7 \\
\hline 計 & 396 & 82 & 20.7 \\
\hline
\end{tabular}

2）出現部位：82 名の癩㶳者に見た 222 個のVSの分 布は顔, 頸部, 前胸部に多く, 次いで背部, 上睕にも比 較的多数に見られ，いつれも上半身に限られていた。VS の出現とその部位の知賞障㥂との間には特別の関係は認 められないように思われた（Tab．5）。強いていえば広 
く顔面では麻缯部に (40:27), その他の部では正常感 覚部に（96:59）幾分多いか子知れない。

Tab. 5 VSの部位別及知覚の状態別出現率

\begin{tabular}{|c|c|c|c|c|}
\hline \multirow{2}{*}{ 部 位 } & \multicolumn{3}{|c|}{ 知 覚 の 状 態 } & \multirow{2}{*}{ 個 数 (\%) } \\
\hline & 麻 痺 & 鈍 麻 & 正 常 & \\
\hline 頭 & 1 & & & $1(0.45)$ \\
\hline 顔 & 35 & 1 & 23 & $59(26.5)$ \\
\hline 項 & & & 2 & $2(0.9)$ \\
\hline 耳 介 & 3 & & 2 & $5(2.2)$ \\
\hline 形 & 10 & 5 & 32. & $47(21.1)$ \\
\hline 前 胸 & 9 & 6 & 26 & $41(18.4)$ \\
\hline 背 & 9 & 1 & 26 & $36(16.2)$ \\
\hline 上 腕 & 6 & 3. & 12 & $21(9.4)$ \\
\hline 前 腕 & 9 & 1 & & $10(4.5)$ \\
\hline 計 & 82 & 17 & 123 & 222 \\
\hline
\end{tabular}

3）VSの形状：形状については諸家の観祭例と同様 に，吾々の経験例でも鮮紅色或は暗赤色，帽針頭大から 踠豆大の略々円形の皮疹であり，中心に血管腫様の隆起 があり，それより各方面に放射状に蛇行した毛細血管脚 が延び，その間に吻合があるものもあればそらでないも のああり，全体として蜘蛛網状或は星芒状を呈するもの が多い。中には鮮紅色の中心点のみを認め毛細血管㑢の

Fig. 1 種々の形状を有する VS

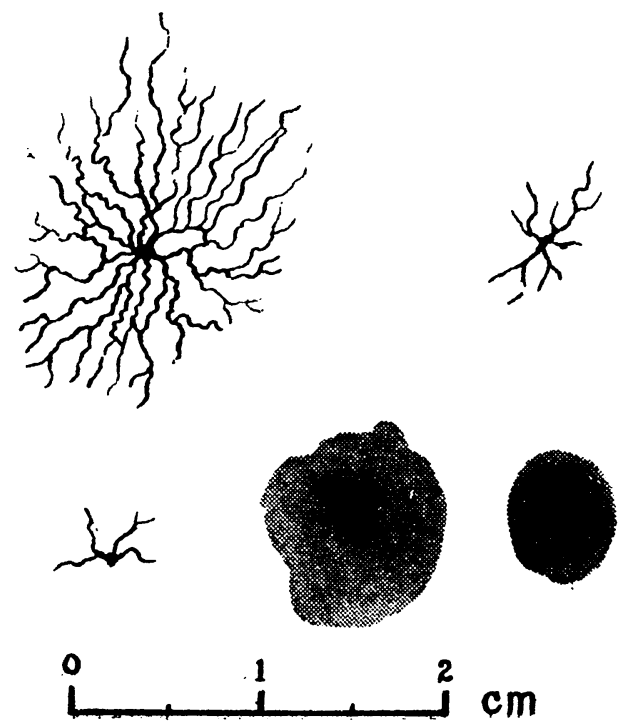

著しく少ないめの，或は中心点を取り四んで淡褐色乃至 紫赤色の円形珻のみを認めるものもあつた。（Fig. 1は 結節瀨患者に認めた種々の形状の皮疹)。顔，頸部，前 胸部等の VS 多発部では定型的なものが多く，前腕部， 手背等では不定型のものが多いととを知つた。

4) 毛細血管挔張の有無：74例の VS 患者中39例には、 程度の差とそあれ，他の部位に単なる皮膚毛細血管抎張 の存在するととを証明し得た。

5）女性乳房との関係：癩患者 228 例について女性乳 房の有無をしらべて 6例 $(2.6 \%)$ を得たが，5ち2例 はVSを伴つたものであつた $(2.9 \%) 。$

6）月経異常との関係：先に井口は当園入園患者女子 119名を調査し，月経困難 $75 \%$ ，周期の不定なるもの 21 吕を認めたが，VSのある女子13例についても8例が月 経異常を訴えていた。

\section{諸検查成樍}

1. 皮虐機能検査：各種の皮眉機能検查法が諸家によ り報告されているが，吾々は Hyaluronidase 反応，毛細 血管抵抗，Histamin 反心（皮膚血量）を実施した。

a. Hyaluronidase 反応：著者の一人井口は先に健康人 及び皮唐疾患々者を対象として Hyaluronidase を用いて 皮膚の抎散に及ぼす影響を㭘索した。今回も同様に5000 単位のSpractor を1.0ccの生理食塧水に浴かし，その0.1 $\mathrm{cc}$ を前腕屈側中央の皮内に注射し，1時間及び24時間後 の紅斑並に発斑面積を判定した。成績は Tab. 6に示す 如く一般㿉患者とVSを伴らものの間に特別変つた所見 は得られなかつた。

Tab. 6 Hyaluronidase 反忘

\begin{tabular}{|c|c|c|c|c|c|}
\hline & 時 間 & & & & \\
\hline 区 & & VS & 霣対照 & VS & 饋対照 \\
\hline & 0 & 6 & 19 & 4. & 32 \\
\hline & $\sim 100$ & 1 & 4 & & 2 \\
\hline 面 & $\sim 200$ & 30 & 71 & 5 & 18 \\
\hline & $\sim 400$ & 14 & 89 & 20 & 69 \\
\hline 皘 & $\sim 600$ & 6 & 13 & 12 & 54 \\
\hline 碽 & $\sim 800$ & & 6 & 3 & 18 \\
\hline 3 & $\sim 1000$ & 1 & 1 & 3 & 7 \\
\hline$Z_{i:}$ & $\sim 2000$ & 1 & 1 & 1 & 8 \\
\hline & $\sim 3000$ & 1 & 3 & & 3 \\
\hline & 計 & 60 & 207 & 48 & 207 \\
\hline & 0 & 6 & 19 & 4 & 32 \\
\hline 反 & - & 5 & 20 & 2 & 6 \\
\hline 応 & \pm & 14 & 76 & 17 & 62 \\
\hline m & + & 28 & 67 & 9 & 47 \\
\hline 虺 & H & 1 & 16 & 8 & 29 \\
\hline 度 & $\mathrm{HH}$ & 6 & 9 & 8 & 31 \\
\hline & 計 & 60 & 207 & 48 & 207 \\
\hline
\end{tabular}


b. 毛細血営抵抗：小方しや製佐藤式紫斑計を用い, -100 mm Hg，1 分間の滛血斑数を鎖骨下部で読んだ。 一般に癩㶳者の毛細血管抵抗は低く，VSを有するもの との間に有意の差を認め得ない(Tab. 7 )。

Tab. 7 毛細血管抵抗

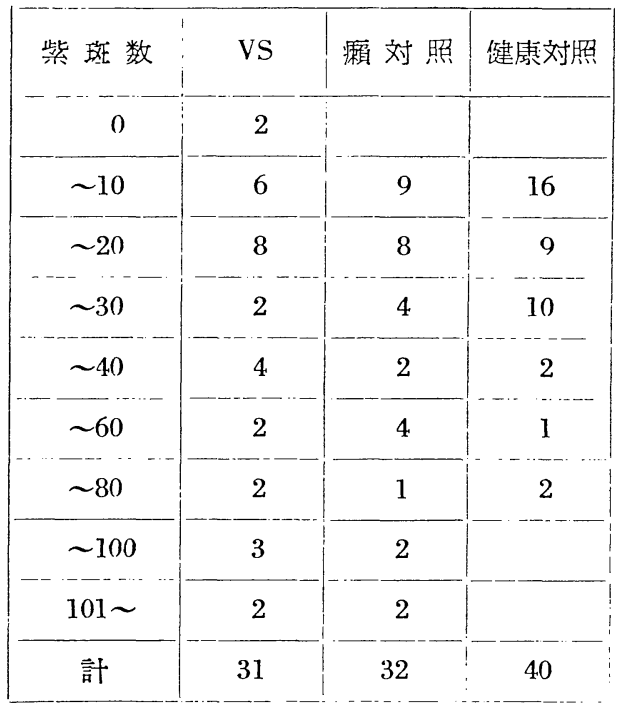

c. Histamin 反応 : 筆者の一人宇都宫は光電 Plethysmographを用いて皮膚血量を測定し，健康人及び皮虚疾 患々者について各種の負荷による皮盧血管の態度を桙討 して来た。その方法に隼じ今回も Histamin $0.005 \mathrm{mg} / \mathrm{kg}$ を注射して典量の変動よりヒスタミン係数（第52回皮夙 科学会総会, 昭28亿㪕告)を算出主ると(Tab. 8), 対照 の瀨患者と同様に VS 患者も高値を示し特有と思われる
変化は見らわない。

Tab. 8 ヒスタミン係数 (HI)

\begin{tabular}{|c|c|c|c|}
\hline H I & VS & 攋 対 照 & 健虚対斯 \\
\hline$\sim 25$ & & 1 & 1 \\
\hline$\sim 30$ & 1 & 7 & 8 \\
\hline$\sim 35$ & 8 & 13 & 7 \\
\hline$\sim 40$ & 1 & 14 & \\
\hline$\sim 45$ & 1 & 2 & \\
\hline $46 \sim$ & & & \\
\hline 計 & 11 & 37 & 16 \\
\hline
\end{tabular}

2. 肝機能検查：肝臟の主なる機能としては，(1)分必 及び排泄機能，(2)糖，蛋白，脂肪等に対する物質代謝に 関する機能，(3)解毒機能等が挙げられ，従来数多くの検 查法が提案された。肝障㥂に際しててれらの部分機能が 一様に犯されているとは限らないし，また同一部分機能 に関する検查成績にも検查方法によつて解離が認められ るので，肝機能障㥂を窥知するには出来る丈多くの検査 方法を併用し反復実施するととが望ましい。この意図の もとに吾々は Tab. 9 の如く6 種の肝機能検査法を択び 肝障碍を実買と間質の両障碍に分ち綜合判定による検 索を試みた。即ち 38 例中実質障碍を 18 例（47.3\%)に 認め，間質障㥂は全例に大なり小なり認めるととが出来 た。

Tab. 9 肝 機能 判定法（飛田）

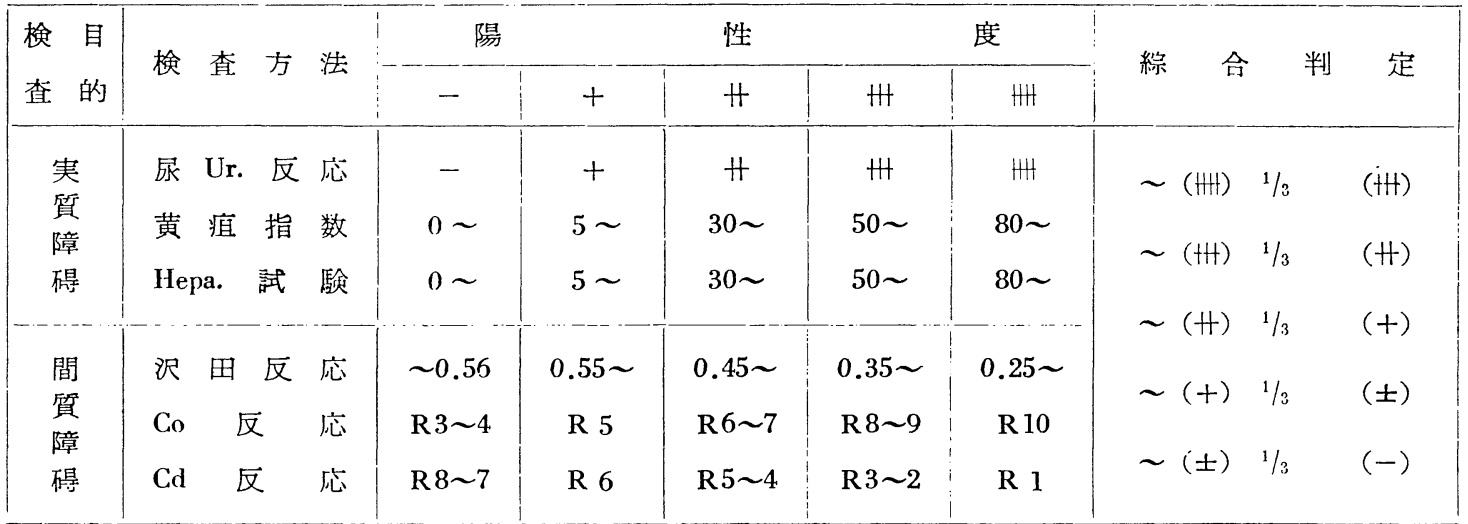

尿 Ur. 反応二尿 Uroqilinogen 反応, Hepa 試験 $=$ Hepatosulfalein 試験，沢田反応＝沢田氏血清昇录反応， Co反応＝血清 Cobalt 反応，Cd 反応＝血清 Cadminium 反応 
Tab. 10 肝機能㭲查成績

\begin{tabular}{|c|c|c|c|c|c|c|c|}
\hline \multicolumn{2}{|c|}{ 榆査方法 } & $\mathrm{HH}$ & $H$ & & & - & 計 \\
\hline 実 & 尿Ur.反応 & 1 & & 10 & & 38 & 49 \\
\hline 質 & 黄疽指数 & & & 11 & & 27 & 38 \\
\hline 障 & Hepa.試験 & & & 5 & & 18 & 23 \\
\hline 碍 & 綜合判定 & & & 6 & 12 & 20 & 38 \\
\hline 聞 & 沢田反忍 & 14. & 21 & 3 & & & 38 \\
\hline 質 & Co 反忍 & & 4 & 9 & & 25 & 38 \\
\hline 障 & Cd 反応 & & 27 & 8 & & 3 & 38 \\
\hline 碍 & 綜合判定 & 5 & 24 & 9 & & & 38 \\
\hline
\end{tabular}

3. 糖代謝：著者の一人伊川はHagedorn 法により空 腹時血糖を測定し，簿蒛糖二重負荷試駼により血楉曲線 を作り，本曲線を 5 種13型に分類した（第 162 回颇虚科 学会福阊地方会，昭28)。瀨患者24名について同様に検 索すると空腹時血糖は 68〜 $116 \mathrm{mg} / \mathrm{dl}$ ，平圴 $92.89 \mathrm{mg} / \mathrm{dl}$ で大体正常範囲内にあつたが，簿萄独二重負荷試験では $20 / 24$ に異常型を示した（らち 1 例は腎性糖尿，真性煻尿 なし)。VS 7 例では全例異常型を認めたが $\mathrm{B}_{1} \sim \mathrm{C}_{1}$ 型に 属し比較的軽度のものであつた。VSのないものでは $/ 17$ の正常型が認められている。（Tab. 11）

Tab. 11 葡萄糖二重負荷試験

\begin{tabular}{|c|c|c|c|c|c|}
\hline 分 & 類 & VS & 癩対照 & 誄 & 健序対照 \\
\hline 正 & $\mathrm{A}_{1}$ & & 2 & \multirow{2}{*}{4} & 10 \\
\hline 型 & $\mathrm{A}_{2}$ & & 2 & & 6 \\
\hline \multirow{3}{*}{ 異 } & $\mathbf{B}_{1}$ & 1 & 2 & 3 & \\
\hline & $\mathrm{B}_{2}$ & 3 & 1 & 4 & \\
\hline & $\mathbf{B}_{3}$ & & & & \\
\hline \multirow{3}{*}{ 型 } & $\mathrm{C}_{1}$ & 3 & 4 & 7 & \\
\hline & $\mathrm{C}_{2}$ & & 3 & 3 & \\
\hline & $\mathrm{C}_{3}$ & & 2 & 2 & \\
\hline 真 性 & $\mathrm{D}_{1} \sim_{4}$ & & & & \\
\hline 腎 性 & $\mathrm{E}$ & & 1 & 1 & \\
\hline \multicolumn{2}{|c|}{ 計 } & 7 & 17 & 24 & 16 \\
\hline
\end{tabular}

4. 自律神経機能検査：本症の10例（結節瀨 8 ，神経

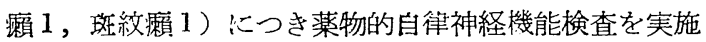

したが，その成績では Tab. 12 に示すように全例に両神 経系の異常を認めた。

Tab. 12 自律神経機能検查成績

\begin{tabular}{|c|c|c|c|c|c|c|c|}
\hline \multirow{2}{*}{ No. } & \multirow{2}{*}{\multicolumn{2}{|c|}{$\begin{array}{c}\text { 年 令 } \\
\text { 性 }^{-1}\end{array}$}} & \multirow{2}{*}{ 病型 } & \multirow{2}{*}{$\begin{array}{l}\text { 経年 } \\
\text { 過数 }\end{array}$} & \multicolumn{2}{|l|}{ 薬 } & 物 \\
\hline & & & & & Adre. & Pilo. & Atro. \\
\hline 1 & 33 & $\delta$ & $\mathrm{L}$ & 17 & \pm & Ht & - \\
\hline 2 & 40 & " & " & 23 & H & + & - \\
\hline 3 & 51 & & " & 6 & $H$ & $H$ & \pm \\
\hline 4 & 42 & & " & 17 & HH & + & + \\
\hline 5 & 40 & " & " & 15 & \pm & - & \pm \\
\hline 6 & 27 & " & " & 12 & \pm & $H$ & - \\
\hline 7 & 34 & " & " & 15 & H & \pm & \pm \\
\hline 8 & 35 & " & " & 16 & H & $H$ & - \\
\hline 9 & 54 & " & $\mathrm{N}$ & 29 & $H$ & $H$ & + \\
\hline 10 & 32 & 우 & M & 15 & $H$ & H & H \\
\hline
\end{tabular}

Fig. 2 Epinephrin-test

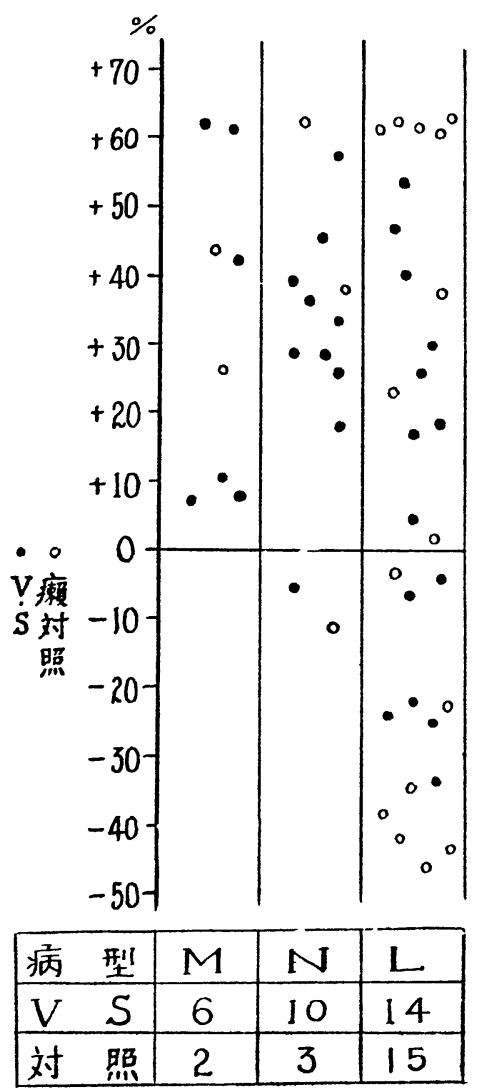


Tab. 13 結節癩患者の基礎代謝（昭和29年 2 月 $3 \sim 4$ 日測定）

\begin{tabular}{|c|c|c|c|c|c|c|c|c|c|c|}
\hline \multirow{2}{*}{ No. } & \multirow{2}{*}{ 性 } & \multirow{2}{*}{ 年令 } & \multirow{2}{*}{$\begin{array}{l}\text { 身 長 } \\
(\mathrm{cm})\end{array}$} & \multirow{2}{*}{$\begin{array}{c}\text { 体 重 } \\
(\mathrm{kg})\end{array}$} & \multirow{2}{*}{$\begin{array}{c}\text { 体表面穦 } \\
\left(\mathrm{m}^{2}\right)\end{array}$} & \multicolumn{2}{|l|}{ 熱 } & \multicolumn{2}{|c|}{ 量 (Cal) } & \multirow{2}{*}{ 備 } \\
\hline & & & & & & $\mathrm{m}^{2} / \mathrm{l}$ 時間 & $\mathrm{kg} / 1$ 日 & $\begin{array}{l}\text { 高比良の } \\
\text { 式, } 1 \text { 日 }\end{array}$ & 1 日 & \\
\hline 1 & 우 & 32.8 & 137.4 & - 35.3 & 1,168 & 35.44 & 28.13 & 1006 & 993 & \\
\hline 2 & " & 21.0 & 152.3 & 44.5 & 1,389 & 32.76 & 24.54 & 1097 & 1092 & \\
\hline 3 & " & 33.3 & 144.0 & 43.1 & 1,316 & 35.15 & 25.75 & 1051 & 1110 & VS \\
\hline 4 & " & 28.1 & 144.4 & 38.9 & 1,262 & 37.89 & 29.49 & 1044 & 1147 & \\
\hline 5 & " & 30.1 & 158.0 & 53.0 & 1,537 & 31.30 & 21.79 & 1028 & 1155 & \\
\hline 6 & " & 40.2 & 155.5 & 44.0 & 1,402 & 34.86 & 26.70 & 1070 & 1175 & \\
\hline 7 & " & 25.0 & 136.0 & 44.0 & 1,274 & 40.30 & 28.00 & 1048 & 1232 & \\
\hline 8 & " & 45.6 & 153.0 & 42.2 & 1,363 & 40.70 & 31.56 & 1049 & 1323 & \\
\hline 9 & " & 34.3 & 151.5 & 53.2 & 1,493 & 42.81 & 28.83 & 1160 & 1534 & \\
\hline 10 & " & 26.1 & 153.0 & 45.9 & 1,412 & 45.30 & 33.44 & 1095 & 1535 & \\
\hline 11 & $\hat{o}$ & 28.5 & 162.3 & 48.0 & 1,502 & 34.57 & 25.96 & 1376 & 1246 & \\
\hline 12 & " & 33.4 & 166.2 & 53.1 & 1,596 & 33.95 & 26.48 & 1411 & 1300 & VS \\
\hline 13 & " & 51.8 & 148.2 & 49.8 & 1,429 & 38.58 & 26.57 & 1224 & 1323 & VS \\
\hline 14 & " & 37.9 & 151.9 & 51.2 & 1,472 & 37.05 & 26.93 & 1305 & 1379 & VS \\
\hline 15 & " & 51.6 & 161.1 & 57.3 & 1,611 & 37.07 & 25.01 & 1355 & 1433 & VS \\
\hline 16 & " & 39.7 & 155.7 & 45.5 & $1,4.52$ & 42.50 & 31.96 & 1292 & 1454 & \\
\hline 17 & " & 30.1 & 163.2 & 54.0 & 1,589 & 39.82 & 28.07 & 1406 & 1516 & \\
\hline
\end{tabular}

5. 基礎代謝：吾々は徳大医学部衛生学教室の協力の るとに結節癩17例につき Douglas-bag 法により基礎代謝 を測定したが動嵒が勊しくはつきりしないけれどもVS のあるすのが幾分低いよらに思われる。（Tab. 13）。

6. Thorn's Epinephrin-test : $1000 \times$ Epinephrin 0.4 cc を皮下注射し 4 時間後の血中好酸球減少率を算出した。 VS 30 例中結節瀨14例では正負の側に2 分された分布を 示し異常型と思われる。玟紋獺 、神経瀨に於てもとの殆 んどが却つて増加して異常域を示した（Fig. 2)。VSの 認められない懶20例についても同様に本椧查を行つたけ れどもすべて異常域值を示して㧊り，下垂体，副腎系の 機能の障㥂を祭知された。

7. その他の検查：脈搏数，血圧及び脈圧（Tab. 14) を測定し，また赤沈及びへマトクリット值 (Tab. 15) を 算出し，蛋白尿（Tab. 16）の榆笨も行つたが，VS 特有 の変化を認めなかつたので詳細については略し表記する に止める。
Tab. 14 血圧，脈圧及び脈搏数（VS）

\begin{tabular}{|c|c|c|c|c|}
\hline 測 & 定 & 倠 & 例数 & 計 \\
\hline \multirow{7}{*}{ 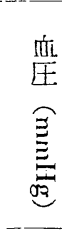 } & 900 & $\sim 100$ & $\overline{5}$ & \multirow{7}{*}{31} \\
\hline & & $\sim 110$ & 6 & \\
\hline & & $\sim 120$ & 8 & \\
\hline & & $\sim 1 \overline{3}$ & 5 & \\
\hline & & $\sim 140$ & 3 & \\
\hline & & $\sim 150$ & 2 & \\
\hline & 151 & $\sim$ & 2 & \\
\hline \multirow{4}{*}{ 脈 } & 20 & $\sim 30$ & 2 & \multirow{6}{*}{31} \\
\hline & & $\sim 40$ & 5 & \\
\hline & & $\sim 50$ & 13 & \\
\hline & & $\sim 60$ & 9 & \\
\hline \multirow[t]{2}{*}{ 正 } & & $\sim 70$ & 1 & \\
\hline & 71 & $\sim$ & 1 & \\
\hline & 60 & $\sim 70$ & 6 & \\
\hline 艇 & & $\sim 80$ & 10 & \\
\hline 搏 & & $\sim 90$ & 9 & 31 \\
\hline 数 & - & $\sim 100$ & 5 & \\
\hline & & & 1 & \\
\hline
\end{tabular}


Tab. 15 赤沈及びへマトクリット值

\begin{tabular}{|c|c|c|c|c|}
\hline 測 & 定 & 值 & VS & 瀨対照 \\
\hline \multirow{2}{*}{ 赤 } & & $\sim 10$ & 7 & 24 \\
\hline & & $\sim 20$ & 8 & 22 \\
\hline 沈 & & $\sim 30$ & 1 & 10 \\
\hline 等 & & $\sim 40$ & & 7 \\
\hline \multirow{3}{*}{ 胥 } & & $\sim 60$ & 2 & 8 \\
\hline & & $\sim$ & 2 & 6 \\
\hline & & 計 & 20 & 77 \\
\hline & & $\sim 30$ & 1 & 6 \\
\hline$\hat{\nabla}$ & & $\sim 40$ & 2 & 17 \\
\hline b & & $\sim 50$ & 7 & 19 \\
\hline \% & & $\sim 60$ & 5 & 24 \\
\hline 值 & & $\sim 70$ & 4 & 9 \\
\hline \multirow[t]{2}{*}{ 质 } & 71 & $\sim$ & 1 & \\
\hline & & 計 & 20 & 75 \\
\hline
\end{tabular}

Tab. 16 蛋白尿

\begin{tabular}{|c|c|c|}
\hline 反応 & VS & 瀬対照 \\
\hline- & 17 & 259 \\
\hline \pm & 2 & 38 \\
\hdashline+ & 12 & 99 \\
\hdashline$H$ & 4 & 24 \\
\hline$H$ & 1 & 14 \\
\hline H & 36 & 439 \\
\hline
\end{tabular}

\section{縂括及び考按}

吾々が観察した VS の性状は鮮紬色乃埾紫赤色で帽針 頭大から踠豆大の類円形の紅班であり，その中央には血 管腫様に隆起した中心点を有し，乙れからすべての方向 に微細な蛇行した放線状の毛細血管脚が延び，全体とし て星艺状，蜘蛛網状或いは花火線香様を呈した。中心は 吾々が前腕部で観察したように中心点を取り国んで潮紬： せるけ形斑のみを認める場合も方り，また鮮糺色の中心 点を認め，放線状の毛細血管の不朋瞭な例もあつたが， Cicovacki(1937)はVSの形成に際しては先づ始めAngiom
様の中心点が出現するといつて颃るので，Angioma tub erosum とするより矢張り VS と考えるのが順当であろ 5。またVS を有する患者に毛細血管昖張の合併を ${ }^{39} / 74$ に認めたが, Laennec 肝硬变症患者にも度々VSとアルコ 一ル性毛細血管詓張が噺存するといわれているから，要 するに症候論的に瀨患者に現われるVS も他の患者に見 られるものと形態上には何等相異が認められないとい完 る。

発生の部位についても同様で Eppinger は前額, 頸部, 項部，雇，前胸部，手背を挙げ，上半身のみに出現する と強調し，Falitischeck, Cicovacki 等も同様の見解を発 表した。Bean も氏の経験した 1720 籄の分布が前胸部 (28.1\%), 上脃 (17.9\%), 肩 (17.5\%), 頸部 (12.5 \%), 顔 $(10.0 \%)$, 前腕 $(3.4 \%)$ の順になつて抢り, 極 めて稀には下半身に現われるとともあるが殆んど上半身 に限るといつていいとの見解を持つて括り，中尾氏等及 び行村教授等の症例もすべて上半身に認められたすので めつた。吾々の観祭例代於てもすべて上半身に限られて いたととは前記の諸家の報告と一致するが，その分布は 顔が最も多く $(26.5 \%)$, 次いで頸部 $(21.1 \%)$, 前胸部 (18.4\%)，背部(16.2\%), 上腕，前腕の順でめつて(Tab. 5 ）多少Bean の報皆と異なり，なた Cicovacki, Bean, 中尾氏等が経験したといら粘膜疹は見出すととが出来な かつた。

VS は何故に上半身に好発するかについては倘決定的 な証明がされていない。Cicovacki は生理的に上半身の 毛細血管の Tonusか下半身のそれより不安定であるため だろらといい，Bean も同様の解彩である。一方皮周の 毛細血管抵抗は身体各部により異なることが知られてお り，Borbely，Franke, Menger, 葷島氏，谷村教授等，ま た教室の横関氏等の報告によると一般に上半身绀下半身 に比べて著しく低いとの事である。谷村教授等は 4 名の 過剩 Fstrogen 投与者（前立腺肥大症患者）の毛細血管 抵抗值を測定して鎖骨下部，扁胛間部，上腕等の投与前 から抵抗值の低い部ではその低下゙が毣明であり，大腿， 下腿等の下半身では殆んど变化を見なかつたと報告し た。宇都葟が光電 Plethysmograph を用いて Histamin に よる皮風血量の変化を顧患者の上下肢に於て比較覾察し た成綪でも下肢の血量の变動は上肢のそれに比して極め て軽微であつた。以上の諸成綪を綜合するとVS の上半 身に好発する機転は皮瘖血管の局所的素因を肯定すれば 説明は容易であり興味樑い問題と考える。

この見解に立つとVS の発現と局所の知党障碍の有無 が問題となる。即ち小松氏は45例の瀨患者につき健常部 
と知覚麻䓬部の皮周毛細血管を皮店顕微鏡を用いて検索 し, 前者ですその傾向は㚣るが特に知党麻淖部では毛細 血管係蹄は長さを増し時に毛細静脈が昖張して拈り，温 熱及び機㭜的刺戟に対する反芯は現われないか或は現わ れても茨いと報皆している。また緒方教授は皮膚温度の

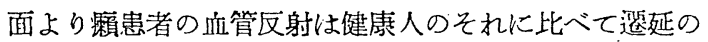
傾向があるけれども知覚障碍の程度が相当に達しても局 所の血管運動は遥かに後迄残るといわれ，宇都富も未㭊 血量の観点から同様のととを実験した。木村氏等は所謂 断節瀨四肢末梢の毛細血管でも血行が良好なるととを報 告し, 毛細血管抵抗との関係について福田氏は知党の有 無による著明な差を認めていない。吾々の観祭例では軀 幹では知党麻䖒部に僅かに発生率が少いのではないかと 思われ，それ以外の部位では知覚障碍部が辀分高率を示 すようであつたがその差は有意でなかつた。（Tab. 5) 要するに皮唐知覚障碍と VS の発生との関連は病期が進 行した場合はある程度考えなければなるすいが，癩その あのに全身性の素因がある以上局所性の知覚障碍は余り 大きな母地とはならないよらに思われる。というのも顆 のVS が年令的には $31 〜 50$ 于のものがその数に於ても $($ 約 $2 / 3)$, 各年令層の率儿於てb多い事笑 (Tab. 2), 経 過年数では11〜20年を経過せるものに多く且つ高率であ つた事 (Tab. 3)，及び病型別では結節瀨に出現率が最 も高く, 斑紋瀨, 神経癩の㮌に減ずる（Tab.4）といら 吾々の成樍は後述の結節癩に肝病変が最も高度でせる事 とも関連しようが，一般には㽸勢経過の進展に伴つて頻 発することを推測せしめ，上記の吾々の見解を物語るる のであろら。

VS の発生病因論は Falitischeck(1936)の器㭜的刺戙説 に始るが，VSが動脈性なる苯が確認され副行静脈と闰 一機序とは考えられなくなる（Patek, 1940）と共に殆儿 ぞ顧みられなくなり，Loeper (1937) はアスコルビン酸 或は血中のチラミンにその原因を求めんとし，Aguilera mauri (1938) は植物神経異常とした。

Cicovacki (1940) の肝機能障碍説及び毒素説は有名で あり，前者は肝機能障碍のために生じた種々の有管な代 謝物質が皮㲊の毛細血管に働きVS を起すといら考えで あり, 後者は肝蔵に対しては肝硬変症を起し毛細血管に 対してはVSを起すような上位の毒素によるものるある との仮説で，加らるに体質的素因を推定したものです る。成程, Eppinger, Cicovacki 等はVSを肝硬变症に極 めて特異的なものであると記載し, Falitischeck はVSが

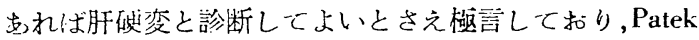
\& Ratnoff $\varnothing$, Bean 等も高率の発生を報じ, 諸家の統
計を綜合し大体 $2 / 3$ に出現するもののようである。本邦で も操教授はVS の存在は Laennec 肝硙变と Banti 病との 鑑別に利用出来るともいわれているが出現率は $17 \%$ との ことでする。

其後Bean（1945）は種々の肘機能娭査を行いVSとの 平行関係をみたが特定のものとの相関を否定した。即ち 氏はVS は肝硬変のみに現われる特異な皮層应状ではな く，極めて稀に肝硬变以外の肝不全，妊婦及びビタミン 欠乏应に見られる場合があるととを指摘して，VSの発 現と性ホルモン特にEstrogen 及び肝機能との相関々係の ある事を記載した。

肝茷が Estrogen を不活性化する事はZondeck（1934）

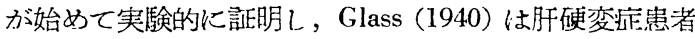
の尿中 Estrogen 值の高いととを報告し，また流行性肋 炎等の肝不全の際に於ける性ホルモン代謝の変動は, Zondeck, Back その他によつて研究された所でする（19 47)。

Lloyd \& Williams (1948)は Bean の説を支持し，肝硬 変の際に現われるVSは恐らく肝㵋が Estrogenを不活性 化する能力を失うために長期に亘る血中過剩 Estrogen又 はこれに類似の 17-Ketosteroid の刺战のために発生する であろらと述べ現在との説に賛成する人は多い。Corbett により始めて発表された妊婦のVS る妊娠中に見られる 軽度の肝機能低下と妊娠による血中の過剩Estrogenの存 在を考え合せるとらなづけるととでもり，また Bean が 臨楽的に肝硬変患者に Estrogen を投与して ${ }^{2} / 3$ 例に VS の発生を観祭し，先年谷村教授等が Estrogen 或は合成 Estrogen を前立腺肥大应患者10例に過剩投与し，5ち2 〜 3 例に可成り著明なVSを，他の者にも程度の軽いVS を発生せしめ，更に家雨について Estrogen の過剩投与 によりVVSの発現を実験的に成功された事実は立派な裏 附けである。

然し Estrogen 説も未だ決定的なるのとはいい難く， Pincus（1951）は肝疾患々者の Gonadotropin, 17-Ketoste roid 及び Estregenの尿中排泄量弆測定し，VSとEstrogen 代謝との間に如何なる相関々俰も認めなかつたと報告し て扣り，芳賀氏も Estrogen 動脈刺戙説の如くある特殊 の原因と考えるのは妥当でないと述べ，後藤名誉教授は 肝硬変の際の皮膚毛細就管の抎張蛇行や更にVSはビタ ミンK欠乏にもとづく毛細血管壁の軟化䭪胀と透過性の 增虺に因るものであると主张されている。

要するにVSの発生要約として現在最も重視されてい るのは肝㹿碍及びてれに直接関連する性ホルモンの失調 であろうと考えられる。成程との様に考えると前述のよ 
ろに肝硬変の $2 / 3$ にS が出現するといら西欧諸家の統計, Bean（1949）が 1423 名の妊婦の約 $2 / 3$ に認めたといら成 樍も納諾出来るわけであるが，吾々が瀨患者に $20.7 \%$ の 高率心 VS を認め, 偶然操教授の肝硬变の際の出現率 17 \%に一致しむしろこれをやや上迴る成績を得たことは， 伊川の一般皮膚疾患々者に於ける罹患率 $0.15 \%$ と比較し 如何にも高率であるよらに感ずる。

然しなから鰿の場合早晚肝汇もJ Jadnssohn か Atrophic and Hypertrophic Cirrhosis と記載した変化の来るとと は既に立証された所であつて，Autopsy 或は Biopsy（阙

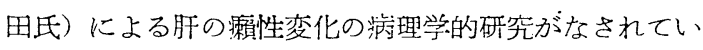
る。諸家の報告 (Jadassolnn, 小林氏, 光田氏, 宗内氏,

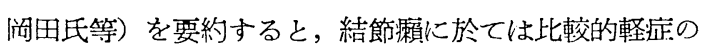
場合には間質の増殖が僅微で被膜下組織，葉間結䋨織の 血管及び葉間静脈の周囲に数個の瀨性空胞細胞よりなる Leprom を生し，ととに若干の小円形細胞の浸潤を伴つ ている。病変が進展してくると間質結蟐織の増殖が次第 に跮くなり小円形細胞浸潤著明となり，Leprom は大き く且つ数を增し小葉間のみならず小葉内にも浸潤を生ず るようになる。肝細胞も殆んどすべて溷濁或は溷濁浮腫 状を呈し，退行性病変著明となり高度の脂肪变性を認め るものが非常に多い。斑紋瀨，神経颊㖽に於ても脂肪変性 を認めるものが多い（小林氏）が，前者では類結核様病 单を証明するものもあり，後者では前者に比べて軽度で あるが時に類結核様病変の不全型にやや近いものも見ら れ特異的な炎症像を示すといら。要するに肝病变は結節 瀨に於て最も著明であり, 斑紋霜, 神経瀨の順に程度が 軽く（VS の出現率と一致する），初期の間質病変は病勢 の進展に伴い実質に波及抎大して障碍は次第に重篤にな るものの如くである。

以上の器質的障䅞は然当肝機能障碍をもたらするので あるととは言を笑たない。既に石橋氏，小松氏，橋本氏 矢野氏等は高田氏反応を，原田氏，行村教授等は高田氏 反心及び Weltmann 凝固带反心を，楊氏は $2 ， 3$ の血清 蛋白反応及び Asorbin-S 試験, Gross 氏反応，尿 Urobilinogen 反応を，また神宫氏等はAsorbin-S 試検及び Hepatosulfalein 試験を瀨患者に試み，瀨患者に於ては一 般に間質，実質とるに障㥂されているとと多く特に結節 瀨汇最も高度であると報告されている。

著者の一人飛田は 2 年来朋障碍と皮成機能の関連を覚 らベく，肝障碍を実質障碍と間質障碍に分けて皮有疾患 々者及び実験的肝障碍家鬼の皮痛機能を㛟討したが（第

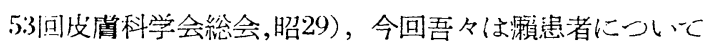
も肺の部分機能を知るため，実質障碍は尿 Urobilinogen
反忘, 黄疽指数, Hepatosulfalein 試験を, 間質障碍は沢 田氏血清昇永反灾, 血清 Cobalt 反応, 血清 Cadminium 反忍を指標として検討したが，との方法は井上教授及び 沢田教授の研究とも一致するものであつだ。即ち井上教 授等は肝の部分機能検査と Needlebiopsy, 手術亚に剖㛟 によつて得た肝組織標本と比較対照し肝組織像の变化と 各種部分機能との関係を検索した結果, 潜在性肝実質障 㑸の場合には尿Urobilinogen 反応，色素負荷試験が最も 銧敏な反応でめり，尿 Urobilinogen 反応, CholesterinEster 比率, 果糖負荷, Santonin 曹達負荷, 安息香酸曹 達負荷試験等により肝実質障碍の程度を比較的よく把握 し得るが，血清高田氏反忍，殊に血清Cobalt反忘，血漿 Prothrombin 值の低下並にビタミン K 負荷後の Prothrombin 值の不变等は間啠の增殖の程度とよく一致してい るとと没報告し，また血清 Cadminium 反応の炎症性疾

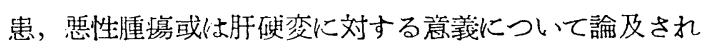
ている。李た沢田教授等によると血清高田氏反忍と同意 義を有する（ｒｏss 氏反忍に於いてハイエム氏液のかわり に昇录水を用いると前二者より反応が一層鋭敏とのとと ではる。

吾々がVS を合併する38例の獺患者について実施した 成績は全く予想の如くその全例に間質障碍を認め $\left({ }^{24} / 38\right.$ は中等度障碍), 半数に実質障碍 (軽度障碍のみ) を認 めたととは肝の器筫障碍の進展と思い合せ注目に価する と思ら。るとより実質障碍のある半数は当然間質の障碍 を合侻しているととは中すまでもないが，その障碍の程 度を見ると間質障碍から始まり病勢の進行とともに実質 障碍が現われて来たものと考えられる。平田氏はチビオ ンの瑇疹としてVS の形をとつた数例を経験したと報 告しているが, プロミン，プロミン゙ール等の治瀨薬によ る肝機能障碍はチビオンのそれに比較して実に少く, 阿 部氏等は対照群に比べて大差ないといつて抢り，橋本氏 等はプロミン注射後漸次肝機能の恢復する場合も多いと 述べて抢り，吾々の観察例に肝障碍の認められたととは 化学療法による肝機能障碍といらよりも矢張り頼性変化 によるものと考えるべきでむろら。本検査成績はVSを 合併したものについての成績でめり，VSの出現が獺の 経過年教11〜15年の者に多いとと, 結節攋患者に多発し たとと $(23.9 \%$ ，全VS の78.7\%）を思らとき肝障碍と VS の出現の間に密接な関係が予想され肝障碍説を否定 するととは出来ない。

さきに伊川は煻代謝の実態を把挃するには葡萄糖二重 負荷試験によるStaub 効果を見るととが最も良い旨報告 L, 營 162 回皮唐科学会福阔地方会, 昭28), その結果 
を程度により 5 種 13 型に表現したが瀨に於て $78 \%$ 異 常型を認めた。しかもVS 合㐼例の 7 例は全例 異常型 を示すととを知つたが，大塚氏，Rajewski，Emerson 等 も重症攋では糖代謝の異常があるととを報じておるから VS 合併者は然らざるもの比にべ広汎な障碍を受けたも のといい得るか歹知れない。但し血煻曲線自体からすれ ばVS 合併者必ずしも高度の変化とはいい得ないから， 㜍代謝を肝の部分機能の一つと考えれしばまた肝機能障碍 説によつて解明さるべきものと考える。

また吾々が攋患者心ついて31\% (137/439)，VS 合併者 について $47 \%\left({ }^{17} / 36\right)$ の尿蛋白陽性者を見たとともPytel 等のい5 Hepatonephritis の概念からすればこの腎障碍 も亦肝障碍を一-次的に考える事が出来るから肝障碍を否 定する材料とはなり得ない。

以上吾々は瀨患者特にVSを合併する者には肝障碍が 基だ高率に見られる事を述べたが，かかる場合 Estrogen を不活性化する能力の減退することは前述の Zondeck, Glass 等の実験的研究が示す所でせる。加らるに瀨病变 が睪丸, 副腎に好発するととは病理組織学的研究の示す 所であり，小林氏は咲丸組織は瀬菌の寄生発育心最適の 臟器とまで極言している状態でむり，畉巣も亦睪丸に劣 るとはいえ胚種層の洀痤化，間質の細胞浸潤，結合織の 増殖が見られる以上当然ここに性ホルモンの不平衡が起 る等で㐫る。この事は臨彇的に身体生毛の異常，初潮の 遅来, 月経異常, 男子の女性乳房, 睪丸の浸潤乃至萎 縮, 陰萎等の症状が比較的屡々観察される事によつて示 されるが，吾々が簡単な下瑟体，副腎皮質系機能をらか がらべく行つた Thorn's Epinephrintest でも大多数が異 常域にめつたととは志賀氏，大西氏，本荘氏等の成績と 略々一致し下垂体，副腎皮質禿機能の低下を考えしめ る。

Aguilera mauri はVS の病因を植物神経異常に求めた が,瀨患者の植物神経機能に関するAubin \& Labernadie, Marras，神宮氏，大森氏等の詳しい報告は吾々が10例に ついて行つた成綪と闹じく何れも植物神経機能の不調和 を示した。森教授の内分必自律神経環境の見地に立ち， また内分必系㙨能と自律神経系との密接な関連を考える と，むしろ植物神経譏能失調は内分必系機能の不平衡に 由来する二次的のものと考えるを妥当としよう。

以上の見地に立つて今仅に性ホルモンのみを聂り上け て見ると，吾々は月経異常者艺96\%(VS合併者では ${ }^{8 / 13}$ ) に諗め，男子の女性乳房を 6 名 $(2.6 \%$ ，VS合併者では $\because / 69$ 即ら $2.9 \%$ ）に発見した。

攋患者に於ける女性乳房を Natali 等（1936）は60例
中14\%に認め，その5ち6名を臨彇的に詳しく検査して 性器発育障碍，睪丸炎，副睪丸炎等の内分泌系の症候群 を見たと記載した。本邦に於ても戸田氏は灀患者1248名 中結節癩に11例 (20.3\%)，神経瀨に 8 例 (11.8\%) に 見て打り，当園の守屋氏もさきに 4 例を報告された。最 近の傾向として前立腺癌, 前立腺肥大应等に Estrogen の 大量投与する場合に本症が屚々見られるととは吾々の日 常経駼する所であるが，癩菌が睪丸を最適の培地として Androgenの産成を抑制すればEstrogenの過剩が女性乳房 を招来するととはまた当然である。一方また肝硬変症の 際に屢々見られるととが諸家により記載され(Silvestrini, Corda, Mithoefer \& Bean, Paula, Bergonzi, Capriglione, Edmondson 等)，睪丸萎縮を伴ら場合が多いといわれて いる。勿論肝硬変以外の肝疾患に於ても観察されて颃 り (Klatskin \& Rappaport, 古川氏等), Rupp等, Gilder \& Hoagland は尿中 Estrogen の排泄を検榃して血中 Estrogenの過剩を弦調し，肝機能障偟による性ホルモン の代謝の变調がその発生機転であるとした。即ち肝障碍 による Estrogen の不活性化が Etrogen の過剩を来し， 一方では女性乳房を来し他方 VSを生ぜしめるとすれば 説明は容易でする。乙の意味に於て吾々が両者の合併を

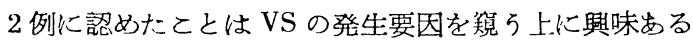
事実でむつた。

以上吾々は瀨患者に高率に発見したVSの発生要因は 一方には瀨病变の進行に伴つて肝の間質障碍に次ぐ実質 障碍が起り，Estrogenの不活性化を阻害して循環Estrogen の過剩を来し，他方瀨性变化が早期にまた虺く睪丸に起 るととによつて逆に Estrogen 過剩状態が惹起されてと こに両者相俟つて VS 発生の条件が完成するものと考え たい。この際瀨菌が卵巣より睪丸に虺い親和性を示すと とが瀬に於けるVS の男性罹患性を高めるかも知れな い。

この様な肝障碍時及びホルモン失調の際皮凬機能に变 異を来すととは既に教公の一連の研究によつて認められ ているので（金子，斎藤，横関，石井，飛田）, 今回 VS を合併し或は合併しない瀨患者の皮成能を検討して見 た。

皮覤機者娭㮅として吾々は前述の 3 種の検索方法を択 んで行つたが，何れにしてもVSに特有なる変化は見ら れずあくまでも癩一般の変化に隼じているよらに思ら。 先づ井口は357例について Hyaluronidase 反応を実施し， 結節癩に於てその反忘が最も弱く，正常人，月経時，皮 成疾患々者に比して一般に弱く，殊に 1 時間及び24時間 後ともに貧血乃至無反応を示すものが16\%す占めている 
のは瀨特有の反応であることを既に発表した（第 9 回皮 膚科学会四国地方会，昭28）。VSについて子同様に貧血 乃全然反応が 1 時間後で 11 例，24 時間後では 6 例もむ り，特徴的な反応と思われるVSがを伴わない瀨対照の 本反応との間には有意の差はない。

毛細血管抵抗について681例（結節瀨55, 神経癩 16 , 斑紋瀨10）に測定を颃こなつたが，一般に正常人に比べ て低值をとり特に絬節瀬に於ては低く，宫尾氏等の報告 と一致した。このらちの発生せる症例でも同様の傾向を 示して括りVS特有とはいえないと思ら。

宇都宫は Histamin 注射による血量の変動曲線からヒ スタミン係数を算出し, 健痛者（平圴30.39）に比べて 瀨患者は一般に大きく（48例平均33.9）殊に結節瀨が最 も高值を示すととを先に発表したが（第10回皮虔科学会 四国地方会, 第20回濑戸内集談会, 昭29), VSを合併し たものも同様で闭者の間に有意の差は認められなかつ た。瀨に於ては組織涧壊物が体内に多く出現するが，光 本氏は体液中にヒスタミン様物質の増加を見た。従つて

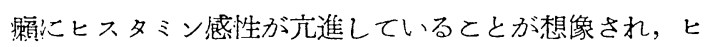
スタミン係数が大となることは容易に考えられる。また 肝障碍でもヒスタミン感性の克進する事実があり(金子) この増加したヒスタミン様物質が皮店毛細血管に作用す れば VSを発生するといら Bean の仮説が成立する。然 し Cicovaeki 等はHistamin を繰返し皮内注射しても VS の発生に失敗し，VS の発生要因はHistaminの様な単純 な物質ではなく禎雑なものであろらとして後に上位の毒 素によると説いた真は先に述べた通りでまる。

以上吾々が行つた 3 種の皮唐機能検査より瀨患者の皮 周感受性の充進している慗は確諗されたけれども，VS の発生した者と然らざる者との間には何ら有急の差を認 め得なかつた。

台癩患者の基礎代謝については，Blum, Maraes 等は 常に上昇しているといい，Marrasは正常者の閾値を越え て増隇しているものが多いと報告し, Ross はその 75.4 \%は正常值内にすり残りのものでも果して瘦による異常 かどらかと疑義を述べ，志損氏等は正常人より低いと記 載している。吾々の観祭例（絬節獺）も少数例で結論は 出し得ないが，遙いてい竞は、 VS 合併例は幾分低值を示 すといえるかも知れない。

\section{結 語}

1）吾々は大島青松園入園患者396例中82例（20.7\%首） にVSを発見した。との数字は一般皮膚科患者心見る発 生率より遥かに大であり, 男子に多発したととが目立
Do

2）VSの発生は結節癩に多く，年令的には31〜50才， 11〜20年の攋の経過年数を持つものに好発する。

3）VS は上半身に多発するが 知覚麻皁との関係は認 められない。

4）VS 合併瀨は全例に肝機能障碍が見られ，間質障 倡が実質障得よりも高度でめる。

5）峬萄糖二重負荷試験により VS 患者は全例異常型 を示した（７例）。

6）自律神経機能は全例に失調が認められた（10例）。

7）Epinephrin-testは何れも異常を認めた。

8）皮唐機能検查は何れも異常であり，VSの合併の 有無による差は明らかでない。

9）男子制患者 228 例中 6 例 $(2.6 \%)$ に，VS合例者 69 例中 2 例 $(2.9 \%)$ に女性乳房を認めた。寽女子の月経 潩常は96\%, VS 患者では61.5\%であつた。

10）VSの発生機序について文献的考察を行い，攋患 者に於ける本症の多発は瀨性变化による肝機能障碍のた め Estrogen 不活性能力が減退し, 内性器その他の内分 泌腺の荒廃が加つて崩中循環 Estrogen が過剩になつた ものと推定した。

（本論文の要旨は昭和29年 4月第27回瀨学会総会にて 発表した。稿を終るに当り御懇切なる御指導と御校閲を 賜つた恩師荒川教授並に野島園長に深謝の意を表し併せ て基礎代謝測定の際御協力下さつた德大医学部衛生学教 室鈴木教授を始め教室員に対し謝意を表する。）

\section{参考文献}

I : Vascular Spider 及び女性乳房

1) Bean, W. B.: Amer. Heart J. 25, 463 (1943)

2) Bean, W. B.: Medicine, 24, 243 (1945)

3) Bean, W. B. et al (S. G. 83, 739, June 1949) : アメリカ医学, 4, 366 (昭24)

4) Cicohvacki, D.: Wien. Klin. Wsch. 35, 478(1940)

5) Eppinger, H.: Die Leberkrankheiten, 613, Julius Springer (1937)

6) Falitischeck: Mitt. ges. int. Med., vom 14 Mai (1936)

7) Glass, S. et al: Skin Manifestations of Internal Disorders, 650 (1940)

8) 後藤: 治療, $33(4) ， 351$ ；（5） $447 ； （ 6 ） 529$ (昭26)

9）装賀：医学研究，22（2），95（昭27）

10）平田：皮周と汹尿，15（6），604（昭28） 
11）伊川：第6回皮膚科学会四国地方会（昭27.6）

12）井口，宇都葟：レプラ，23（4），204（昭29）

13) Lloyd, C. W. \& Williams, R. H.: Amer. J. Med., 4, 315 (1948)

14) 操：日本消化器病学誌，32（11)，697（昭 8)； 臨㸛と研然，25(11)，556（昭23）

15）守屋：レプラ，22（6），330（昭28）

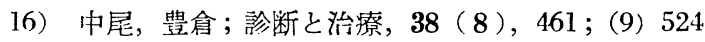
(昭25)

17) Natali et al (Leprosy Rev., 7, 1936): レプラ, 7 (3)，501（昭11）

18）西原，富；臨壯皮必，7（9），543（昭28）

19) Patek, A. G. et al: Amer. J. Med. Sc.، 200, 34.1 (1940)

20) Patek, A. G.: A Textbook of Medicine, 863 (1948)

21) Pincus: Gatsroenterology, 19, 735 (1951)

22) 浴村, 吉野: 治療, $35(9)$, 938 (昭 28$)$

23) 户田：レブラ，8（1），13(昭12)

24）角尾：臨牀の日本，9，54（昭16）

25) Wilson, E.: Manifestations of Internal Disorders, 649 (1869)

26) Rupp, J. et al : J. Clin. Endocrin., 11, 688 (1951)

27）吉川，明石：医療，6（7），463（昭27） II : 瀨及び諸種検查

28）荒川，他：最新医学， 7 (11)，89（昭27）

29）阿部，他：レプラ，20（2），50（昭26）

30) Borbely: Münch. Med. Wschr. 21, 886 (1930)

31) Franke: Zschr. Klin. Med., 137, 86 (1937)

32）橋本他：レプラ，7（3），385（昭11）

33）橋本，佐藤：レプラ，19（1），26（昭25）

34）本䓅：レプラ，22（4)，200（昭28）

35）福田：レプラ, 20 (5)，153 (昭26)

36）原田：レプラ, 8（1)，221（昭12），11(4)，413
(昭15)

37) 井上, 藤时：最新医学， 7 (2)，121（昭27）

38）石橋: 東京医專新誌，No. 2957，17（昭17）

39) Jadassohn, J. : Hdb. d. Pathogen. Mikroorganismen, XII, 2, 1063 (1928)

40）金子：医学研究，24（9），1821（昭29）

41) 小林: 内茞瀨に就て (1928)

42）小松: レプラ，7（1），170（昭11）

43) 小松: 皮尿誌，41（1），75（昭12）

44) Marras, A.(Giorn. ital. Dermat. 72, 1931): レプ ラ, $3(\mathbf{1}) ， 42$ (昭 7)

45) Menger: Klin. Wschr., 9, 1301

46) 光田：癩に関する論文，第 $1 ・ 2$ 輯

47) 光本：レプラ， 12 (5)，535 (昭16)

48）宮尾，他：レプラ，22（4），199（昭28）

49）宗内: 治療及処方, 220 号, 1200 (昭13)

50) 緒方：レプラ，22（4)，158（昭28）

51）岡田：レプラ，22（6），298（昭28）；23(1),

1,8 (昭29)

52) 大森：皮尿誌，38（3），527（昭10）

53）大西：レプラ，22（4），160（昭28）

54) 大塚：皮尿誌，33（2），127（昭 8)

55）斎藤，宇都富：皮性誌，63（4），236（昭28）

56）佐藤，谷村，桜根：日本皮虞科全書，9，1（昭29）

57）沢田:日本医事新報，No. 1442，1519（昭26）

58）志賀，波多：レプラ，22（4），160（昭28）

59）志賀，八木：レプラ，20.(2)，42（昭26）

60) 谷村, 矢野: レプラ, 8 (1)，228（昭12）

61）矢野他：レプラ, $7(3), 443$ (昭11)

62）楊：レプラ，19(1)，3(昭25)

63）横関：皮性誌，62（4），72（昭27）

64) 神袁：レプラ，4（1），1（昭 8）

65）神宮，他：レプラ，22（5），150（昭26） 